\title{
Bioinsecticidal effect of Tagetes erecta (Asteraceae) on the pine sawfly Zadiprion vallicola (Diprionidae)
}

\section{Efecto bioinsecticida de Tagetes erecta (Asteraceae) sobre la mosca sierra del pino Zadiprion vallicola (Diprionidae)}

\author{
Edgar Toribio-Hernández ${ }^{*}$ and Yajaira Cecilia Grande-Romero'
}

\footnotetext{
Comisión Nacional Forestal. Región Costa Chica de

Guerrero. Copala, Guerrero, México.

* Corresponding author. edconres@gmail.com
}

\begin{abstract}
The present study was carried out with the purpose of evaluating the bioinsecticidal effect of Tagetes erecta leaves on larvae of Zadiprion vallicola. Water, acetone and ethanol extracts of T. erecta leaves were extracted by maceration. The extracts were applied in concentrations of $250 \mathrm{mg} / \mathrm{L}, 500 \mathrm{mg} / \mathrm{L}, 750$ and $1000 \mathrm{mg} / \mathrm{L}$ and distilled water used as control. Mortalities were corrected in proportion and an analysis of variance was performed. In addition, the $\mathrm{LC}_{50}$ was calculated for the various extracts obtained. There were differences in mortality in concentrations $(\mathrm{F}=171.4, \mathrm{p}<0.001)$, between solvents $(\mathrm{F}=1060, \mathrm{p}<0.001)$ and in their interactions $(\mathrm{F}=7.3, \mathrm{p}<0.001)$. For the control group the mortality was null, due to the extracts; the greater mortalities were presented in applications greater than $500 \mathrm{mg} / \mathrm{L}$. As concentrations increased, mortality marked a tendency to stabilize. Acetone and ethanolic extracts, with mortalities of 0.81 and 0.96 , were highly effective compared to water extracts with a mortality of 0.64 . The ethanol extracts produced an $\mathrm{LC} 50$ of $63.1 \mathrm{mg} / \mathrm{L}$ and the acetonic extracts of $64.5 \mathrm{mg} / \mathrm{L}$, low concentrations compared to that produced by the water extracts of $398.1 \mathrm{mg} / \mathrm{L}$. The effects of these extracts on the mortality of $Z$. vallicola are similar to those reported for the entomopathogenic fungus Metarbizium anisopliae, and therefore represent a valuable alternative for its control, especially in the case of ethanol extracts.
\end{abstract}

KEYWORDS: ethanol extracts; maceration; Pinus oocarpa; probit regression.

\section{RESUMEN}

El presente estudio fue realizado con la finalidad de evaluar el efecto bioinsecticida de hojas de Tagetes erecta sobre larvas de Zadiprion vallicola. Para ello, se extrajeron por maceración extractos de agua, acetona y etanol de las hojas de T. erecta. Se aplicaron en concentraciones de $250 \mathrm{mg} / \mathrm{L}, 500 \mathrm{mg} / \mathrm{L}, 750$ y $1000 \mathrm{mg} / \mathrm{L}$ y agua destilada como control. Se calcularon las mortalidades corregidas en proporción y se realizó un análisis de variancia. Además, se calculó la $\mathrm{LC}_{50}$ para los diversos extractos obtenidos. Se presentaron diferencias de mortalidades entre las concentraciones $(F=171.4, p<0.001)$, entre solventes $(F=1060, p<0.001)$ y en las interacciones $(F=7.3$, $p<$ 0.001). En el grupo de control la mortalidad fue nula, debido a los extractos; las mayores mortalidades se presentaron en aplicaciones mayores a $500 \mathrm{mg} / \mathrm{L}$. Al aumentar las concentraciones la mortalidad marcó una tendencia a estabilizarse. Los extractos de acetona y etanol, con mortalidades de 0.81 y 0.96 , fueron altamente efectivos comparados con los extractos de agua con mortalidad de 0.64 . Los extractos de etanol produjeron una $\mathrm{LC}_{50}$ de $63.1 \mathrm{mg} / \mathrm{L}$ y los de acetona de $64.5 \mathrm{mg} / \mathrm{L}$, bajas concentraciones comparadas con la que produjeron los extractos de agua de $398.1 \mathrm{mg} / \mathrm{L}$. Los efectos de estos extractos sobre la mortalidad de Z. vallicola, son similares a los registrados para el hongo entomopatogeno Metharizium anisopliae, por lo que representan una valiosa alternativa para su control, especialmente en el caso de los extractos etanólicos.

PALABRAS CLAVE: extractos etanólicos, maceración; Pinus oocarpa; regresión probit. 


\section{INTRODUCTION}

Pine forests have been damaged throughout the world by opportunistic pests, which generally occur after a fire, drought or fragmentation (Hernández, 2012). From the numerous pests, ones that stand out are the bark beetles and defoliating insects (Amri, Gargouri, Hamrouni, Hanana, Fezzani \& Jamoussi, 2012). In Mexico, as in most countries, chemical products and entomopathogenic fungi have traditionally been used for control of forest pests in pines (Cibrián-Tovar, Méndez-Montiel, CamposBolaños, Yates-III \& Flores-Lara, 1995). In the last decades, it has been suggested that biological resources should only be used to fight the contamination of water sources and the deterioration of environmental services caused by the use of chemicals (Fernández-Pavía, Rodríguez-Alvarado, Gómez-Dorantes, Gregorio-Cipriano \& Fernández-Pavía, 2013).

In the northern and western parts of Mexico, pine sawfly (Zadiprion vallicola Rohwer) has caused a loss of up to 15000 ha per zone in a single year (Hernández, 2012; Velez \& Salas, 2012; Ordaz-Silva et al., 2017). It has been suggested during recent years, that biological control should be carried out with hyper parasite insects, mainly wasps, whose effect has been slow and inefficient (Hodge \& Dvorak, 2000; García, 2012). A successful case has been the use of the entomopathogenic fungus Metarbizium anisopliae, which at $1 \times 10^{8}$ conidia per millimeter of concentration has been used as an effective measure against sawfly Monoctenus sanchezi (Ordaz-Silva et al., 2017). As an alternative, extracts of plants with insecticidal effects can be tested for the control of Zadiprion vallicola, an option not used to date for forest pests (Krishna, Prajapati, Bhasney, Tripathi \& Kumar, 2005).

Tagetes erecta L., a plant endemic to Mexico and Central America, known as cempasúchil, clavel chino, african marigold or botón de oro, has been widely studied for its medicinal effects on humans. It is also known for being a biocide against fungi, bacteria, viruses, nematodes and insect pests from vegetable crops, has suitable characteristics to combat larval insect states and whose effectiveness has been tested for the control of Z. vallicola (Krishna et al., 2005; Oranday, Martínez, Nuñez, Rivas \& Flores, 2008; Aldana-Llanos et al., 2012; Joshi, 2015; Padalia \& Chanda, 2015). The main extracts obtained from this plant against insects are flavonoids and terpenes. These extracts have larvae repellent properties against Diptera and Lepidoptera orders, with leaves being the main source of bioinsecticidal substances (Wang, Hanhong \& Shanhuan, 2001; Xu, Wang \& Shi, 2007; Geris et al., 2012; Xu, Chen Qi \& Shi, 2012; Palacios et al., 2015; Selvam, Devaraj \& Rani, 2015; Shetty, Sakr, Al-Obaidy \& Shareef, 2015). It is of great importance to investigate the possibility of using this plant as biological control of larvae of the sawfly $Z$. vallicola in Pinus oocarpa. Particularly important is to know if it has a success similar to that reported in the literature for M. anisopliae, since in other studies it had an effect on mortality similar to that caused by $T$. erecta, for example, against Spodoptera frugiperda (Lezama et al., 2005; AldanaLlanos et al., 2012).

\section{OBJECTIVES}

To evaluate the bioinsecticidal effect of Tagetes erecta leaves on larvae of Zadiprion vallicola.

\section{MATERIALS AND METHODS}

In July 2015, in a temperate agricultural plot of the state of Guerrero located at $16^{\circ} 56^{\prime} 23.7 ” \mathrm{~N}, 98^{\circ} 31^{\prime} 22.5$ ” W, seeds of T. erecta were thrown in parallel rows on a surface of $40 \mathrm{~m} \times 40 \mathrm{~m}$. The crop was maintained with direct sunlight and natural irrigation in the rainy season. Organic fertilizer (cow dung and pine leaf litter) was applied 20 days after cultivation of the plot. On November 15th, 2015, the mature plants were collected separating the leaves of the specimens. The leaves were allowed to dry in the shade for 10 days. Once dried and pulverized, $500 \mathrm{~g}$ were placed in three $4 \mathrm{~L}$ containers. In one of these containers water was added until the material was covered completely; in two others acetone and ethanol were added in a similar way and allowed to macerate for three days. At the end of the maceration, the vegetable remains were separated by filtration with filter paper no. 1 and the solvents were 
separated by a water bath. The filtered extracts were diluted in distilled water to a final concentration of $250 \mathrm{mg} / \mathrm{L}, 500$ $\mathrm{mg} / \mathrm{L}, 750$ and $1000 \mathrm{mg} / \mathrm{L}$ and distilled water was used as the control (Krishna et al., 2005; Oranday et al., 2008; Aldana-Llanos et al., 2012).

The larvae of $Z$. vallicola were removed from the leaves of individuals of Pinus oocarpa in a random and manual form during November 20th to 25 $5^{\text {th }}, 2015$ (Cibrián-Tovar et al., 1995). The site is a pine forest in the state of Guerrero located at $16^{\circ} 56^{\prime} 23.3^{\prime \prime} \mathrm{N}, 98^{\circ} 31^{\prime} 21.2^{\prime \prime} \mathrm{W}$, between 1500 $\mathrm{m}$ and $1700 \mathrm{~m}$ a.s.l. 5200 larvae were collected, which were placed in plastic boxes of $(10 \times 10 \times 10) \mathrm{cm}$ in groups of 20 larvae per box, in a total of 260 boxes. The boxes were covered with mosquito netting to allow the larvae to breathe. For their feeding, leaves of the same individual of $P$. oocarpa from which they were fed were collected and placed covering $50 \%$ of the volume of each box, the leaves being renewed daily at 07:00 h. During the study, the boxes were placed under laboratory conditions at $28{ }^{\circ} \mathrm{C} \pm 0.3{ }^{\circ} \mathrm{C}$ and $61 \%$ H.R. $\pm 2 \%$ H.R.

The study was carried out from November 26th to December 1st, 2015. In each box some of the extracts were applied in their various concentrations, by spraying for three seconds at a separation of $10 \mathrm{~cm}$. Acetone extract at $250 \mathrm{mg} / \mathrm{L}$ was applied in 20 boxes, at $500 \mathrm{mg} / \mathrm{L}$ in another 20 boxes and at the same number of boxes for $750 \mathrm{mg} / \mathrm{L}$ and $1000 \mathrm{mg} / \mathrm{L}$. The same criterion was applied for the application of ethanol extracts and water extracts. In the case of the control it was applied in 20 boxes. The number of live and dead larvae was recorded at 6 days and mortalities were recorded in corrected proportions relative to the control (Cibrián-Tovar et al., 1995; Ordaz-Silva et al., 2017). Lethal concentrations in which half of the larvae die (LC50) were calculated by applying the different extracts at their various concentrations using a probit regression (Aldana-Llanos et al., 2012; Joshi, 2015).

In order to analyze the dynamics of the effect of the different treatments of the extracts, a two-factor ANOVA test was performed using the Past 3.11 program (Hammer, Harper \& Ryan, 2001), using solvent (ethanol, acetone, water) and the concentration (250, 500, 750 and 1000) $\mathrm{mg} / \mathrm{L}$ as factors. For this test the units of mortality were previously transformed in arcsin. After the ANOVA test, Tukey's tests were performed to determine if there were significant differences between treatments.

\section{RESULTS}

At the end of the six days in the control boxes there was zero mortality. The highest mortality of 0.96 was caused by ethanol extracts, followed by acetone at 0.81 (Table 1 and Fig. 1). It is possible to observe that from the application of $500 \mathrm{mg} / \mathrm{L}$ or more, the mortality caused by the different extracts is stabilized (Fig. 1). The highest $\mathrm{LC}_{50}$ lethal effect was that of ethanol calculated at $63.1 \mathrm{mg} / \mathrm{L}$, followed by acetone calculated at $64.5 \mathrm{mg} / \mathrm{L}$ (Table 2, Fig. 2). Among the treatments, there were significant differences (Table 3) and ethanol extracts of $T$. erecta could be considered as successful to control Z. vallicola larvae.

TABLE 1. Mean mortalities \pm standard deviation caused by the application of different extracts of Tagetes erecta on larvae of Zadiprion vallicola

\section{Mortality (proportion)}

\begin{tabular}{lccc} 
& Water extracts & Acetone extracts & Ethanol extracts \\
\cline { 2 - 4 } $250 \mathrm{mg} / \mathrm{L}$ & $0.38 \pm 0.04$ & $0.67 \pm 0.06$ & $0.79 \pm 0.05$ \\
$500 \mathrm{mg} / \mathrm{L}$ & $0.55 \pm 0.03$ & $0.74 \pm 0.05$ & $0.93 \pm 0.06$ \\
$750 \mathrm{mg} / \mathrm{L}$ & $0.60 \pm 0.04$ & $0.78 \pm 0.06$ & $0.94 \pm 0.05$ \\
$1000 \mathrm{mg} / \mathrm{L}$ & $0.64 \pm 0.05$ & $0.81 \pm 0.04$ & $0.96 \pm 0.03$
\end{tabular}




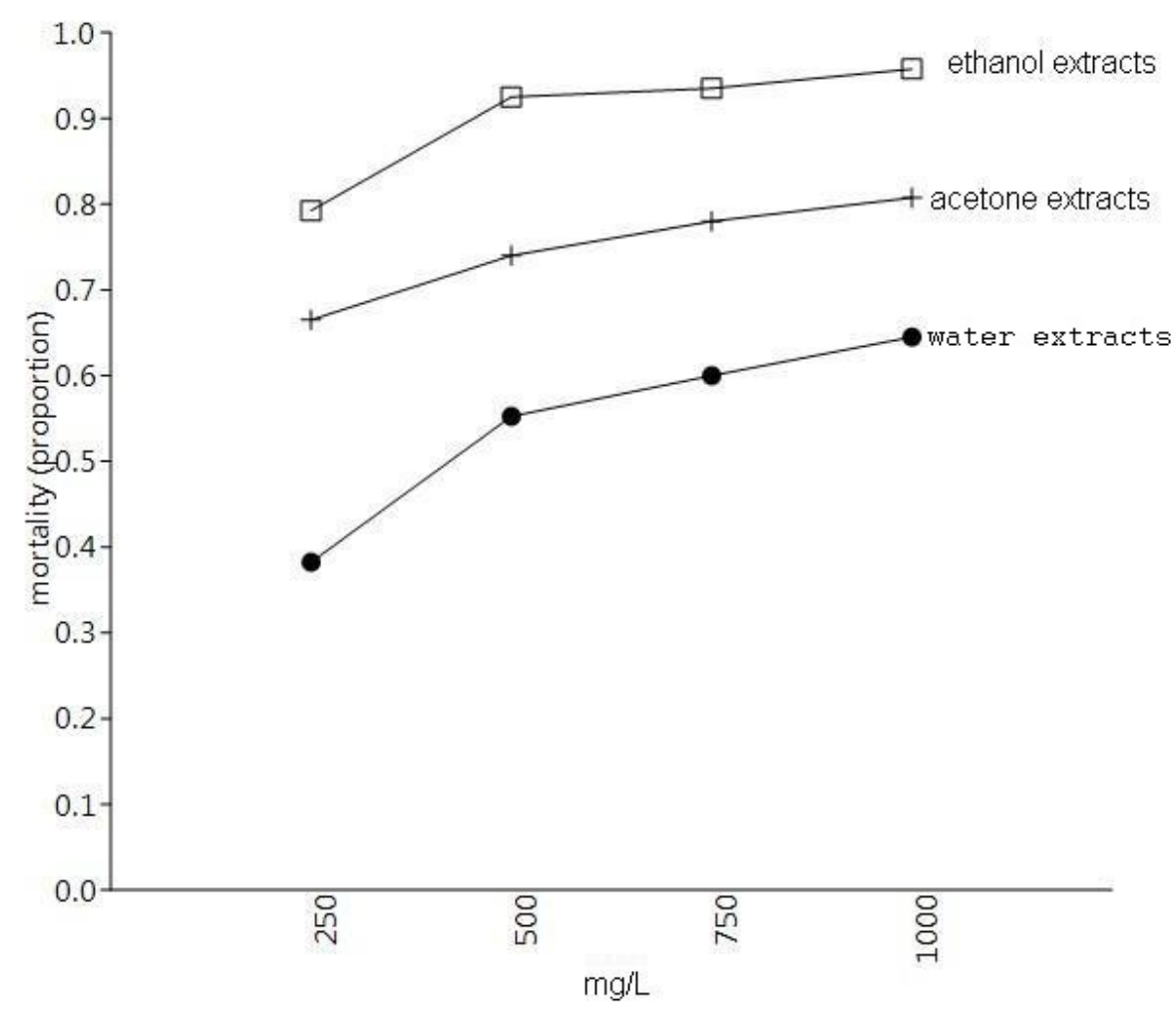

FIGURE 1. Graph of means for mortality caused on larvae of Zadiprion vallicola of three extracts of Tagetes erecta at four different concentrations.

TABLE 2. Lethal Concentration of Different Extracts of Tagetes erecta Causing 50\% Mortality of Zadiprion vallicola Larvae

\begin{tabular}{|c|c|c|c|}
\hline \multicolumn{4}{|c|}{ LC 50 at 6 days } \\
\hline & $\mathrm{mg} / \mathrm{L}$ & $X^{2}$ & $p$ \\
\hline Water extracts & 398.1 & 0.0012 & $>0.05$ \\
\hline Acetone extracts & 64.5 & 0.2318 & $>0.05$ \\
\hline Ethanol extracts & 63.1 & 0.9938 & $>0.05$ \\
\hline
\end{tabular}

Note: LC 50 (lethal concentration with $50 \%$ of mortality) 


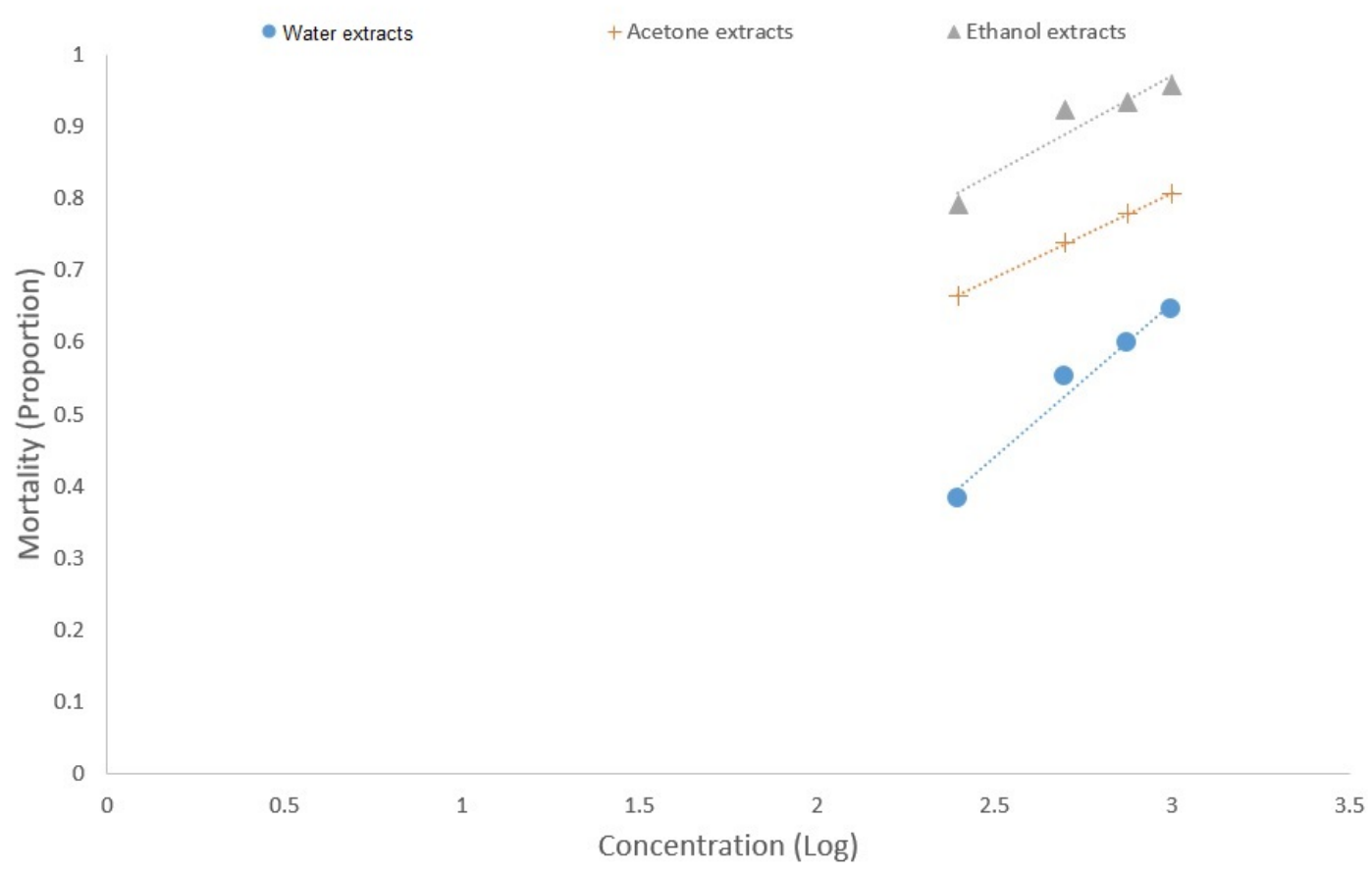

FIGURE 2. Mortality (in corrected proportion) caused by the application of three extracts of Tagetes erecta on larvae of Zadiprion vallicola in four different concentrations (Log).

TABLE 3. Results of Two-Way ANOVA about the effect of concentration and type of solvent of extracts of Tagetes erecta on mortality caused in larvae of Zadiprion vallicola

Two Factors ANOVA

\begin{tabular}{cccc}
\hline Factors & $\mathrm{F}$ & $\mathrm{P}$ & Treatments equal $^{*}$ \\
\cline { 2 - 4 } Concentration (ppm) & 171.4 & $<0.001$ & None \\
Solvent & 1060 & $<0.001$ & None \\
Interaction & 7.3 & $<0.001$ & $\begin{array}{c}\text { Water extracts at } 750 \mathrm{mg} / \mathrm{L} \text { and } 1000 \mathrm{mg} / \mathrm{L} \\
\text { Acetone extracts at } 500,750 \mathrm{mg} / \mathrm{L} \text { and } 1000 \mathrm{mg} / \mathrm{L} \\
\text { Ethanol extracts at } 500 \mathrm{mg} / \mathrm{L}, 750 \mathrm{mg} / \mathrm{L} \text { and } 1000 \mathrm{mg} / \mathrm{L}\end{array}$ \\
\hline
\end{tabular}

Note: * If the probability of the Tukey's Q value between pairs > 0.05

\section{DISCUSSION}

Biological controls for pest control in agricultural crops can be extended to forest pests (Leonti, Sticher \& Heinrich, 2003; Navarro, da Silva, da Silva, Napoleão and Paiva, 2013; Miller et al., 2015; Padalia and Chanda, 2015). The results of the present study show that it is possible to test the extracts of plants used in agricultural crop pests and try them in the forest field (Fernández-Pavia et al., 2013; and Selvam et al., 2015). Most studies on the allelopathic effects of various plant extracts on various pests focus on the application of laboratory extractions as the present research, which facilitates their interpretation and comparison (Singh, Batish \& Kohli, 2001; Wang et al. , 2001; Xu et al., 2012; Shetty et al., 2015). Following these ideas, the success of the 
T. erecta ethanol extracts in this study are similar to those reported with $M$. anisopliae, in both cases causing mortality greater than 0.95 (in proportion) in sawflies (Ordaz-Silva et al. 2017). Similarly, $60 \mathrm{mg} / \mathrm{L}$ of leaves of Datura stramonium (known as toloache) cause a mortality of $52.2 \%$, although unlike this, T. erecta does not have the inconvenience of being toxic to humans. (Flores-Villegas et al., 2019).

Ethanol extracts of T. erecta can be performed relatively easily and can be used effectively in places where Z. vallicola pests are present, which can be rapidly advanced (SáenzRomero, Guzmán-Reyna \& Rehfeldt, 2006; FernándezPavia et al., 2013). This species in larval state has its highest activity at the end of November of each year, in a relevant way the same month in which $T$. erecta reaches its maturity (Cibrián-Tovar et al., 1995; Hernández, 2012; Shetty et al. 2015). This tuning allows using the macerated product of this plant, with effectiveness and without the need to add preservatives, to be able to apply almost immediately to its elaboration; in addition, it is notable that there is no deficiency of this plant, since it is a traditional crop in rural areas bordering forests (Leonti et al., 2003).

A number of plants with allelopathic effect against pests, such as viruses, bacteria, fungi and insects in humans and vegetable crops for human consumption, have been studied (Wang et al., 2001; Shetty et al. 2015). In the present study, it is demonstrated that they can be used in pests that afflict forests, using previous knowledge about the effects on similar groups of organisms (Velez \& Salas, 2012; Fernández-Pavia et al., 2013). The case of T. erecta is outstanding because it has effects at the level of human disease, in vegetable crops and in this case in forest diseases, which can be presented as a pan-allelopathic plant (Kalemba \& Kunicka, 2003; Narayanaswamy, Gleiser, Chalannavar \& Odhay, 2014; Padalia \& Chanda, 2015; Palacios et al., 2015; Selvam et al., 2015). Its distribution in the five continents has proved to be beneficial at the ornamental, medicinal and agronomic levels and the present study reinforces this view (Wang et al., 2001; Leonti et al., 2003; Xu et al., 2012; Fernández-Pavia et al., 2013; Shetty et al., 2015). (Flores-Villegas et al., 2019).

\section{CONCLUSIONS}

The ethanolic extracts of T. erecta at a concentration of 63.1 $\mathrm{mg} / \mathrm{L}$ caused the death of $50 \%$ of the larvae of $Z$. vallicola, at a concentration of $1000 \mathrm{mg} / \mathrm{L}$, causing death of $96 \%$.

Under controlled conditions, extracts of T. erecta are as effective as the biological controls traditionally used.

It is necessary to carry out field studies that demonstrate the real similarity between the application of extracts of T. erecta and other biological controls.

\section{ACKNOWLEDGMENTS}

Sincere thanks to Mirian Gutierrez of the University of California at Santa Barbara for the revision of the manuscript.

\section{REFERENCES}

Aldana-Llanos, L., Salinas-Sánchez, D. O., Valdés-Estrada, M. E., Gutierrez-Ochoa, M. Rodríguez, E. Y., \& Navarro-García, V. M. (2012). Biological activity of dose extracts of Tagetes erecta L. on Spodoptera frugiperda (J.E. Smith). Southwestern Entomologist, 37(1), 31-38. doi: 10.3958/059.037.0104

Amri, I., Gargouri, S., Hamrouni, L., Hanana, M., Fezzani, T., \& Jamoussi, B. (2012). Chemical composition, phytotoxic and antifungal activities of Pinus pinea essential oil. Journal of Pest Science, 85(2), 199-207. doi: 10.1007/s10340-012-0419-0

Bashir, S. \& Gilani, A. H. (2008). Studies on the antioxidant and analgesic activities of Aztec marigold (Tagetes erecta) flowers. Phytotherapy Research, 22(12),1692-1694. doi: 10.1002/ptr.2550

Cibrián-Tovar, D., Méndez-Montiel, J. T., Campos-Bolaños, R., YatesIII, H. O., \& Flores-Lara, J. E. (1995). Insectos Forestales de México. México: Universidad Autónoma Chapingo.

Fernández-Pavía, S. P., Rodríguez-Alvarado, G., Gómez-Dorantes, N., Gregorio-Cipriano, M. R., \& Fernández-Pavía, Y. L. (2013). Enfermedades en plantas en el Estado de Michoacán. Biológicas, 14(2), 75-89

Flores-Villegas, M. Y., González-Laredo, R. F., Prieto-Ruíz, J. A., Pompa-García, M., Ordaz-Díaz, L. A., \& Domínguez-Calleros, P. A. (2019). Eficiencia del extracto vegetal de Datura stramonium L. como insecticida para el control de la mosca sierra. Madera $y$ Bosques, 25(1), e2511642. doi: 10.21829/myb.2019.2511642

García, J. L. M. (2012). Enfermedades Presentes en el Pino Durante la Etapa de Vivero, en el Campo Experimental Forestal Barranca de Cupatitzio, Michoacán. Revista Mexicana de Ciencias Forestales, 16(70), 69-85. 
Geris, R., Ribeiro, P. R., da Silva Filho, M. I., Silva, H. H., Silva, I. G., \& Brandao, M. (2012). Bioactive natural products as potential candidates to control Aedes aegypti, the vector of dengue. Studies in natural products chemistry, 37(1), 277-376. doi: 10.1016/B978-0-44459514-0.00010-9

Hammer, Ø., Harper, D. A. T., \& Ryan, P. D. (2001). PASTPaleontological Statistics Software Package for Education an Data Analysis. Palaeontologia Electronica, 4(1), 1-9.

Hernández, M. S. H. (2012). Observaciones sobre los insectos que dañan a Pinus radiata Don en la Región Central de México. Revista Mexicana de Ciencias Forestales, 11(60), 75-84.

Hodge, G. \& Dvorak, W. (2000). Differential responses of Central American and Mexican pine species and Pinus radiata to infection by the pitch canker fungus. New Forests, 19(3), 241-258. doi: 10.1023/A:1006613021996

Joshi, B. (2015). Comparative study of essential oil of Tagetes erecta (Asteraceae) against third instar larvae of Aedes aegypti (Linnaeus, 1762) and Anopheles stephesi (Liston, 1902). European Journal of Biotechnology and Bioscience, 3(6), 20-23.

Kalemba, D. \& Kunicka, A. (2003). Antibacterial and antifungal properties of essential oils. Current medicinal chemistry, 10(10), 813829. doi: 10.2174/0929867033457719

Krishna, A., Prajapati, V., Bhasney, S., Tripathi, A. K., \& Kumar, S. (2005). Potential toxicity of new genotypes of Tagetes (Asteraceae) species against stored grain insect pests. International Journal of Tropical Insect Science, 25(02), 122-128. doi: 10.1079/IJT200560

Leonti, M., Sticher, O., \& Heinrich, M. (2003). Antiquity of medicinal plant usage in two Macro-Mayan ethnic groups (Mexico). Journal of ethnopharmacology, 88(2), 119-124. doi: 10.1016/S03788741(03)00188-0

Lezama, R., Molina, J., López, M., Pescador, A., Galindo, E., Ángel, C. A., \& Michel, A. C.(2005). Efecto del hongo entomopatogeno Metarbizium anisopliae sobre el control del gusano cogollero del maiz en campo. Avances en Investigación Agropecuaria, 9(1), 1-5.

Narayanaswamy, V. K., Gleiser, R. M., Chalannavar, R. K., \& Odhay, B. (2014). Antimosquito properties of 2-substituted phenyl/benzylamino-6-(4-chlorophenyl)-5-methoxycarbonyl-4methyl-3, 6-dihydropyrimidin-1-ium chlorides against Anopheles arabiensis. Medicinal Chemistry, 10(2), 211-219. doi: 10.2174/157340641002140131164945

Navarro, D. M. A. F., da Silva, P. C. B., da Silva, M. F. R., Napoleão, T. H., \& Paiva, P. M. G. (2013). Larvicidal activity of plant and algae extracts, essential oils and isolated chemical constituents against Aedes aegypti. The Natural Products Journal, 3(4), 268-291. doi: $10.2174 / 221031550304140328113732$
Miller, A. B., Cates, R. G., Lawrence, M., Espinoza, L. V., Martínez, J. V., \& Arbizú, D. A. (2015). The antibacterial and antifungal activity of essential oils extracted from Guatemalan medicinal plants. Pharmacentical biology, 53(4), 548-554. doi: 10.3109/13880209.2014.932391

Oranday, A., Martinez, G., Nuñez, A., Rivas, C., \& Flores, A. E. (2008). Coumarin isolated from Tagetes lucida Cav. exhibits larvicidal activity in Aedes aegypti (L.). Southwestern Entomologist, 33(4), 315317. doi: 10.3958/0147-1724-33.4.315

Ordaz-Silva, S., Chacón-Hernández, J. C., Hernández-Juárez, A., CernaChávez, E., Castro del ángel, E., \& Gallegos-Morales, G. (2017). Efecto de hongos entomopatogenos sobre larvas de mosca sierra (Monoctenus sancheri Smith). Southwestern Entomologist, 42(1), 221224. doi: $10.3958 / 059.042 .0120$

Padalia, H. \& Chanda, S. (2015). Antimicrobial Efficacy of Different Solvent Extracts of Tagetes erecta L. Flower, Alone and in Combination with Antibiotics. Applied Microbiology: Open Access, 1(1), 1-10. doi:10.4172/2471-9315.1000106

Palacios-Landín, J., Mendoza-de Gives, P., Salinas-Sánchez, D. O., López-Arellano, M. E., Liébano-Hernández, E., HernándezVelázquez, V. M., \& Valladares-Cisneros, M. G. (2015). In vitro and in vivo Nematocidal Activity of Allium sativum and Tagetes erecta Extracts Against Haemonchus contortus. Türkiye Parazitolojii Dergisi, 39(4), 260-264. doi: 10.5152/tpd.2015.4523

Sáenz-Romero, C., Guzmán-Reyna, R. R., \& Rehfeldt, G. E. (2006). Altitudinal genetic variation among Pinus oocarpa populations in Michoacán, Mexico: implications for seed zoning, conservation, tree breeding and global warming. Forest Ecology and Management, 229(1), 340-350. doi:10.1016/j.foreco.2006.04.014

Selvam, S. I. K., Devaraj, R., \& Rani, C. (2015). Allelopathic Effect of Tagetes erecta on Soil Microbes and Nematodes of Papaya. Indo American Journal of Pharmaceutical Research, 5(10), 3210-3219.

Shetty, L. J., Sakr, F. M., Al-Obaidy, K., Patel, M. J., \& Shareef, H. (2015). A brief review on medicinal plant Tagetes erecta Linn. Journal of Applied Pharmacentical Science, 5(3), 091-095. doi: 10.7324/JAPS.2015.510.S16

Singh, H. P., Batish, D. R., \& Kohli, R. K. 2001. Allelopathy in agroecosystems: an overview. Journal of Crop Production, 4(2), 1-41. doi:10.1300/J144v04n02_01

Velez, R. M. \& Salas, F. I. (2012). Morfología de Zadiprion vallicola Roh. (Hymenoptera Diprionidae). Revista Mexicana de Ciencias Forestales, 10(57), 3-14.

Wang, X., Hanhong, X. U., \& Shanhuan, Z. (2001). Progress in insecticidal plant marigold, Tagetes erecta. Journal of Xi'an United University, 5(2), 5-10. 
Toribio-Hernández and Grande-Romero. Bioinsecticidal effect of Tagetes erecta on Zadiprion vallicola

Xu, L. W., Chen, J., Qi, H. Y., \& Shi, Y. P. (2012). Phytochemicals and their biological activities of plants in Tagetes L. Chinese Herbal Medicines, 4(2), 103-117. doi:10.3969/j.issn.16746384.2012.02.004

Xu, L. W., Wang, G. Y., \& Shi, Y. P. (2007). Chemical constituents from Tagetes erecta flowers. Chemistry of Natural Compounds, 47(2), 281283. doi: 10.1007/s10600-011-9905-5.

Received: 8 May 2017

Accepted: 8 August 2019

Published: 11 April 2020
This paper must be cited as:

Toribio-Hernández, E. \& Grande-Romero, Y. C. (2020). Bioinsecticidal effect of Tagetes erecta (Asteraceae) on the pine sawfly Zadiprion vallicola (Diprionidae). Madera $y$ Bosques, 26(1), e2611564. doi: 10.21829/myb.2020.2611564

Madera y Bosques by Instituto de Ecología, A.C. is distributed under a Creative Commons Licence Attribution-NonCommercial-ShareAlike $\quad 4.0$ Internacional. 